\title{
Carbon Dioxide versus Air Insufflation in Gastric Endoscopic Submucosal Dissection: A Systematic Review and Meta-Analysis of Randomized Controlled Trials
}

\author{
Ramkaji Baniya, Sunil Upadhaya, Jahangir Khan, Suresh K Subedi, Tabrez S Mohammed, Balvant K Ganatra and Ghassan Bachuwa \\ Department of Internal Medicine, Hurley Medical Center/Michigan State University, Flint, MI, USA
}

Background/Aims: Endoscopic submucosal dissection (ESD) with air insufflation is commonly used for the staging and treatment of early gastric carcinoma. However, carbon dioxide $\left(\mathrm{CO}_{2}\right)$ use has been shown to cause less post-procedural pain and fewer adverse events. The objective of this study was to compare the post-procedural pain and adverse events associated with $\mathrm{CO}_{2}$ and air insufflation in ESD.

Methods: A systematic search was conducted for randomized control trials (RCTs) comparing the two approaches in ESD. The Mantel-Haenszel method was used to analyze the data. The mean difference (MD) and odds ratio (OR) were used for continuous and categorical variables, respectively.

Results: Four RCTs with a total of 391 patients who underwent ESD were included in our meta-analysis. The difference in maximal post-procedural pain between the two groups was statistically significant $(\mathrm{MD},-7.41 ; 95 \%$ confidence interval $[\mathrm{CI}],-13.6--1.21$; $p=0.020)$. However, no significant differences were found in the length of procedure, end-tidal $\mathrm{CO}_{2}$, rate of perforation, and postprocedural hemorrhage between the two groups. The incidence of overall adverse events was significantly lower in the $\mathrm{CO}_{2}$ group $(\mathrm{OR}$, 0.51 ; CI, $0.32-0.84 ; p=0.007)$.

Conclusions: $\mathrm{CO}_{2}$ insufflation in gastric ESD is associated with less post-operative pain and discomfort, and a lower risk of overall adverse events compared with air insufflation. Clin Endosc 2017;50:464-472

Key Words: Carbon dioxide insufflation; Air insufflation; Endoscopic submucosal dissection; Early gastric carcinoma; Post-procedural pain

\section{INTRODUCTION}

The lifetime risk of developing gastric cancer in the United States is $0.9 \%$. It is estimated that 26,370 new cases of gastric cancer were diagnosed in 2016 alone, and that 10,730 people died of it. ${ }^{1}$ Worldwide, it is the third highest leading cause of cancer-related death. ${ }^{2}$ Early gastric carcinoma in the United

Received: November 25, 2016 Revised: March 26, 2017

Accepted: March 29, 2017

Correspondence: Ramkaji Baniya

Department of Internal Medicine, Hurley Medical Center/Michigan State University, One Hurley Plaza, Suite 212, Flint, MI 48503, USA

Tel: +1-810-262-9000, Fax: +1-810-262-7245, E-mail: mail2ramkazi@gmail.com

(cc) This is an Open Access article distributed under the terms of the Creative Commons Attribution Non-Commercial License (http://creativecommons.org/ licenses/by-nc/3.0) which permits unrestricted non-commercial use, distribution, and reproduction in any medium, provided the original work is properly cited.
States accounts for about $20 \%$ of the total cases of gastric cancer. ${ }^{3}$

Endoscopic submucosal dissection (ESD) helps in both the staging and treatment of early gastric carcinoma. It is a well-established technique for en bloc removal of gastrointestinal (GI) epithelial lesions. ${ }^{4-10}$ However, this procedure is technically demanding and time consuming. Extensive gas insufflation is required to maintain optimal visualization during the procedure. Compared with standard air insufflation, carbon dioxide $\left(\mathrm{CO}_{2}\right)$ insufflation has been found to be safe and effective in various studies. ${ }^{11-16} \mathrm{CO}_{2}$ is absorbed 160 times more rapidly than nitrogen and 13 times more rapidly than oxygen across the intestine into the blood. Hence, it is easily excreted by the lungs. ${ }^{17}$ Our aim was to evaluate the safety and efficacy of $\mathrm{CO}_{2}$ insufflation in terms of maximal end-tidal $\mathrm{CO}_{2}$ during the procedure, procedure length, and 

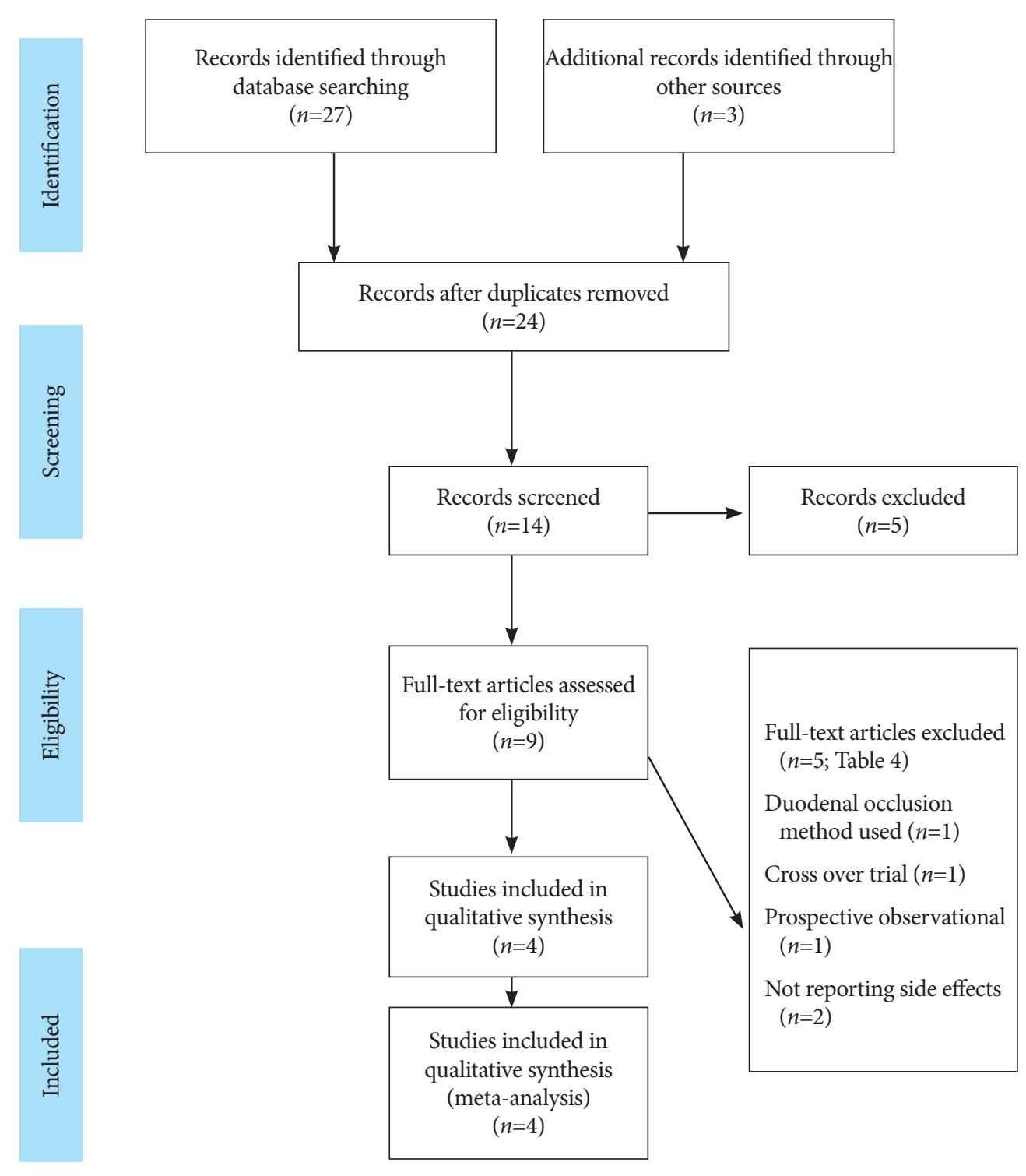

Fig. 1. Preferred reporting items for systematic reviews and meta-analysis statement of systematic search.

Table 1. Results of Quality Assessment by Delphi Consensus Criteria

\begin{tabular}{|c|c|c|c|c|}
\hline Final Delphi List & Tanioka et al. $^{23}$ & Kim et al. ${ }^{24}$ & Maeda et al. ${ }^{25}$ & Takada et al. $^{26}$ \\
\hline \multicolumn{5}{|l|}{ Treatment allocation } \\
\hline a) Was a method of randomization performed? & $\mathrm{Y}$ & $\mathrm{Y}$ & $\mathrm{Y}$ & $\mathrm{Y}$ \\
\hline b) Was the treatment allocation concealed? & NA & $\mathrm{N}$ & NA & NA \\
\hline $\begin{array}{l}\text { Were the groups similar at baseline regarding the most important } \\
\text { prognostic indicators? }\end{array}$ & NA & $\mathrm{Y}$ & $\mathrm{Y}$ & $\mathrm{Y}$ \\
\hline Were the eligibility criteria specified? & NA & $\mathrm{Y}$ & $\mathrm{Y}$ & $\mathrm{Y}$ \\
\hline Was the outcome assessor blinded? & NA & NA & NA & NA \\
\hline Was the care provider blinded? & NA & $\mathrm{Y}$ & $\mathrm{Y}$ & NA \\
\hline Was the patient blinded? & NA & $\mathrm{Y}$ & $\mathrm{Y}$ & NA \\
\hline $\begin{array}{l}\text { Were point estimates and measures of variability presented for the } \\
\text { primary outcome measures? }\end{array}$ & $\mathrm{Y}$ & $\mathrm{Y}$ & $\mathrm{Y}$ & $\mathrm{Y}$ \\
\hline Did the analysis include an intention to treat? & $\mathrm{Y}$ & $\mathrm{Y}$ & $\mathrm{Y}$ & $\mathrm{Y}$ \\
\hline
\end{tabular}

Y, yes; N, no; NA, not available. 
incidence of adverse events as compared with air insufflation in gastric ESD.

\section{MATERIALS AND METHODS}

The Preferred Reporting Items for Systematic Reviews and Meta-Analysis (PRISMA) statement for reporting meta-analysis and systemic reviews, as recommended by the Cochrane Collaboration, was used for this meta-analysis (Fig. 1). ${ }^{18}$ We included all relevant studies published up to November 2016. Medline, Embase, Cochrane library, and clinicaltrials.gov databases were used to identify the studies. The search was conducted using four broad themes. For the theme of carbon dioxide, the all field terms "carbon dioxide" and " $\mathrm{CO}_{2}$ " were used. For the theme of air, the all field terms "air" and "room air" were used. For the theme gastric cancer, all field terms "gastric", "stomach", "early gastric carcinoma", "gastric carcinoma", and "gastric tumor" were used. For endoscopic submucosal dissection, the all field terms "endoscopic submucosal dissection", "ESD", "endoscopic treatment", and "endoscopic procedure" were used. The results were combined using the Boolean operator "AND".

All results were reviewed. No language restrictions were used and all necessary measures to prevent data duplication were taken. Two different investigators (RB and SU) conducted the search and excluded the studies that did not meet the inclusion criteria. Relevant data extracted by the two investigators was corroborated by two other investigators (JK and SKS). A fifth investigator was consulted whenever any issue arose (TSM). The eligibility criteria for the included studies relied on previously published guidelines for systematic reviews and was based on the PICO framework; P (population-patients with early gastric cancer undergoing ESD), I (interventions- $\mathrm{CO}_{2}$ insufflation), $\mathrm{C}$ (comparative interventions-control group, air insufflation), and $\mathrm{O}$ (outcomes-procedure-related primary or secondary adverse events including post-procedural pain and discomfort and pulmonary dysfunction). ${ }^{19}$ Studies that did not compare $\mathrm{CO}_{2}$ insufflation with air were excluded. ${ }^{11,20-22}$ A total of four randomized control trials (RCTs) met the inclusion criteria. ${ }^{23-26}$ Three of them had been

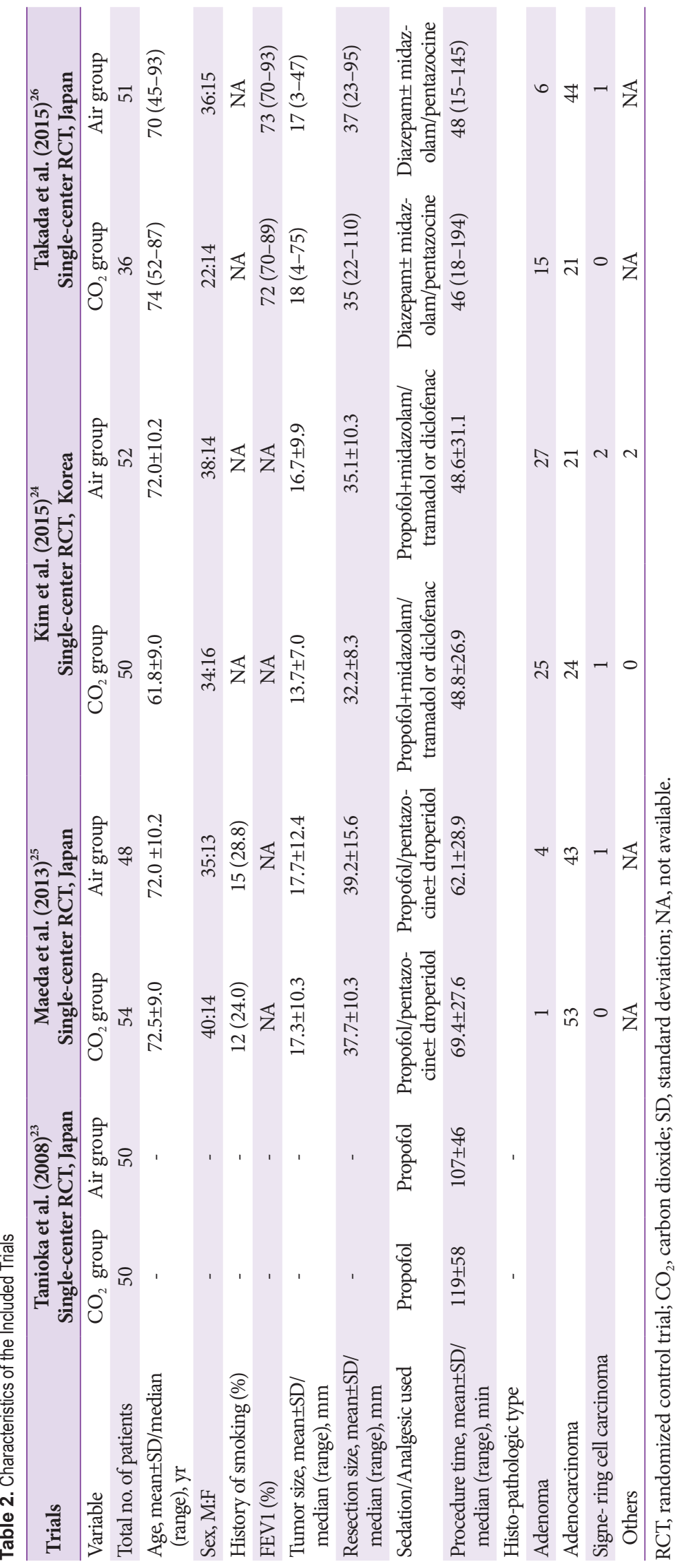


Table 3. Adverse Events of Endoscopic Submucosal Dissection in the Carbon Dioxide Insufflation and Air Groups

\begin{tabular}{|c|c|c|c|c|c|c|c|c|}
\hline \multirow{2}{*}{$\begin{array}{l}\text { Trials } \\
\text { Adverse events }\end{array}$} & \multicolumn{2}{|c|}{ Tanioka et al. $(2008)^{23}$} & \multicolumn{2}{|c|}{ Maeda et al. $(2013)^{25}$} & \multicolumn{2}{|c|}{ Kim et al. $(2015)^{24}$} & \multicolumn{2}{|c|}{ Takada et al. $(2015)^{26}$} \\
\hline & $\mathrm{CO}_{2}$ group & Air group & $\mathrm{CO}_{2}$ group & Air group & $\mathrm{CO}_{2}$ group & Air group & $\mathrm{CO}_{2}$ group & Air group \\
\hline $\begin{array}{l}\text { Abdominal pain post pro- } \\
\text { cedure on } 100-\mathrm{mm} \text { visual } \\
\text { analog scale }\end{array}$ & $\begin{array}{l}14.3 \pm 20.5 \\
\quad(1 \mathrm{hr})\end{array}$ & $\begin{array}{l}24.3 \pm 25.3 \\
\quad(1 \mathrm{hr})\end{array}$ & $\begin{array}{c}4(0 \mathrm{hr}) \\
4(1 \mathrm{hr}) \\
3(3 \mathrm{hr}) \\
1 \text { (next day) }\end{array}$ & $\begin{array}{c}3(0 \mathrm{hr}) \\
4(1 \mathrm{hr}) \\
3(3 \mathrm{hr}) \\
4 \text { (next day) }\end{array}$ & $\begin{array}{l}2.0 \text { (baseline) } \\
35.2(1 \mathrm{hr}) \\
27.8(3 \mathrm{hr}) \\
9.2(24 \mathrm{hr})\end{array}$ & $\begin{array}{c}1.9 \text { (baseline) } \\
48.5(1 \mathrm{hr}) \\
42.5(3 \mathrm{hr}) \\
21.9(24 \mathrm{hr})\end{array}$ & NA & NA \\
\hline $\begin{array}{l}\text { Volume of residual gas in the } \\
\text { digestive tract post-procedure/ } \\
\text { change in abdominal girth }\end{array}$ & NA & NA & $643 \mathrm{~mL}$ & $1,037 \mathrm{~mL}$ & $+0.9 \mathrm{~cm}$ & $+1.5 \mathrm{~cm}$ & NA & NA \\
\hline Post-procedure hemorrhage & 0 & 0 & 1 & 1 & 9 & 15 & 0 & 4 \\
\hline Perforation & 1 & 4 & 1 & 3 & 0 & 0 & 1 & 1 \\
\hline Aspiration pneumonia & 0 & 0 & 0 & 0 & 0 & 0 & 3 & 5 \\
\hline Mallory-Weiss tears & 0 & 0 & NA & NA & NA & NA & 0 & 8 \\
\hline Paroxysmal atrial fibrillation & 0 & 0 & 1 & 0 & NA & NA & - & - \\
\hline Other adverse events & 0 & 0 & Fever (23) & $\begin{array}{l}\text { Stricture } \\
\text { with dys- } \\
\text { phagia (1) } \\
\text { Fever (25) }\end{array}$ & None & None & Fever (9) & Fever (9) \\
\hline \multicolumn{9}{|l|}{$\begin{array}{l}\text { End-tidal } \mathrm{CO}_{2} \text { partial pres- } \\
\text { sure, mean } \pm \mathrm{SD} / \text { median } \\
\text { (range), } \mathrm{mm} \mathrm{Hg}\end{array}$} \\
\hline Baseline & - & - & $37.1 \pm 3.8$ & $38.2 \pm 4.6$ & NA & NA & $39(28-52)$ & $40(22-51)$ \\
\hline Maximum & $48.8 \pm 4.8$ & $50.0 \pm 5.5$ & $40.6 \pm 4.3$ & $41.5 \pm 4.4$ & NA & NA & $52(43-68)$ & $51(40-64)$ \\
\hline $\begin{array}{l}\text { Minimum oxygen saturation, } \\
\text { mean } \pm \mathrm{SD} / \text { median (range), } \%\end{array}$ & - & - & $94.3 \pm 3.0$ & $94.0 \pm 2.4$ & NA & NA & $98(90-100)$ & $98(89-100)$ \\
\hline
\end{tabular}

$\mathrm{CO}_{2}$, carbon dioxide; $\mathrm{SD}$, standard deviation; $\mathrm{NA}$, not available.

published in peer-reviewed journals, ${ }^{24-26}$ and one was a published abstract. ${ }^{23}$ The quality of each study was evaluated by two investigators (BKG and GB) using the Delphi consensus criteria for RCTs (Table 1). ${ }^{27}$

From all the selected studies, we extracted the baseline study details: the type of study, mean patient age, history of smoking, FEV1 (\%), tumor size, resection size, mean procedural size and histological type, and adverse events (Table 2). Six outcomes were measured: procedural length, maximal end-tidal $\mathrm{CO}_{2}$, maximal post-operative pain, post-procedural hemorrhage, perforation, and overall adverse events (Table 3). Overall adverse events included post-procedural hemorrhage, bowel perforation, aspiration pneumonia, Mallory-Weiss tear, paroxysmal atrial fibrillation, and other adverse events (such as fever, and stricture with dysphagia) (Table 3). The outcomes were calculated with Review Manager (RevMan, version 5.3 for Windows; The Cochrane Collaborations, The Nordic Cochrane Centre, Copenhagen, Denmark, 2014). Analysis was performed by the Mantel-Haenszel test using RevMan. Mean difference (MD) was calculated for continuous variables, whereas the odds ratio (OR) was calculated for categorical variables using a con- fidence interval (CI) of 95\%. Heterogeneity was calculated using $I^{2}$. A randomized model was used because low heterogeneity is typically a major problem in small sample size reviews. ${ }^{28} \mathrm{~A} p$-value of $<0.05$ was considered significant. Mean values were estimated from the median using a modified Hozo's formula. ${ }^{26,29}$ The characteristics of the trials evaluated during the study are presented in Table 4 .

\section{RESULTS}

A total of 391 patients were included in the four RCTs. The severity of abdominal pain was measured using a $100-\mathrm{mm}$ visual analog scale (VAS). ${ }^{30}$ Maximal post-operative pain was significantly lower in the $\mathrm{CO}_{2}$ insufflation group compared with the air group (MD, -7.41; 95\% CI, -13.6--1.21; $p=0.02$; Fig. 2). However, procedural time (MD, 5.97; CI, $-0.77-12.72$; $p=0.08$; Fig. 3) and maximal end-tidal $\mathrm{CO}_{2}(\mathrm{MD},-0.14$; $\mathrm{CI}$, $-2.04-1.76$; $p=0.88$; Fig. 4 ) were not significantly different. A total of 125 adverse events (post-procedural hemorrhage, perforation, aspiration pneumonia, Mallory-Weiss tear, paroxysmal atrial fibrillation, and others) were reported (Table 
Table 4. Characteristics of the Trials Reviewed during the Analysis

\begin{tabular}{|c|c|c|c|c|c|}
\hline Study & Year & Design & $\begin{array}{l}\text { Sample } \\
\text { size }\end{array}$ & Conclusion of the study & $\begin{array}{c}\text { Included in data } \\
\text { synthesis }\end{array}$ \\
\hline Suzuki et al. ${ }^{21}$ & 2010 & $\begin{array}{l}\text { Prospective } \\
\text { observational study }\end{array}$ & 100 & $\begin{array}{l}\text { Partial pressure of carbon dioxide throughout the } \\
\text { endoscopic submucosal dissection was within con- } \\
\text { trollable range under general anesthesia and was } \\
\text { little enhanced by prolongation of the procedure }\end{array}$ & No \\
\hline Takano et al. ${ }^{11}$ & 2011 & $\begin{array}{l}\text { Prospective cross-over } \\
\text { trial }\end{array}$ & 60 & $\begin{array}{l}\text { Carbon dioxide is similar in safety compared to air } \\
\text { insufflations during endoscopic submucosal dissec- } \\
\text { tion under deep sedation }\end{array}$ & No \\
\hline Takada et al. $^{22}$ & 2015 & $\begin{array}{l}\text { Prospective } \\
\text { observational study }\end{array}$ & 322 & $\begin{array}{l}\text { No significant difference between pulmonary dys- } \\
\text { function and no pulmonary dysfunction group in } \\
\text { term of end-tidal carbon dioxide before, during } \\
\text { and after the endoscopic submucosal dissection } \\
\text { was found }\end{array}$ & No \\
\hline Takada et al. ${ }^{26}$ & 2015 & $\begin{array}{l}\text { Randomized } \\
\text { controlled trial }\end{array}$ & 116 & $\begin{array}{l}\text { No significant different between two groups in term } \\
\text { of adverse effects except for significantly lower in- } \\
\text { cidence of Mallory-Weiss tears in carbon dioxide } \\
\text { insufflation group }\end{array}$ & Yes \\
\hline Kim et al. ${ }^{24}$ & 2015 & $\begin{array}{l}\text { Randomized double- } \\
\text { blinded, controlled } \\
\text { prospective study }\end{array}$ & 110 & $\begin{array}{l}\text { Reduction in abdominal pain and analgesic usage } \\
\text { significant in carbon dioxide insufflation group } \\
\text { compared to air group }\end{array}$ & Yes \\
\hline Maeda et al. ${ }^{25}$ & 2013 & $\begin{array}{l}\text { Randomized, double } \\
\text { blind, controlled } \\
\text { prospective trial }\end{array}$ & 102 & $\begin{array}{l}\text { Significant reduction in the residual gas volume in } \\
\text { carbon dioxide group compared to air group, but } \\
\text { no difference in abdominal pain or distention }\end{array}$ & Yes \\
\hline Tanioka et al. ${ }^{23}$ & 2008 & $\begin{array}{l}\text { Randomized } \\
\text { controlled trial- } \\
\text { abstract }\end{array}$ & 95 & $\begin{array}{l}\text { Carbon dioxide insufflation is safe and effective in } \\
\text { reducing post-procedure pain in endoscopic sub- } \\
\text { mucossal dissection under propofol sedation }\end{array}$ & Yes \\
\hline Mori et al. ${ }^{20}$ & 2011 & $\begin{array}{l}\text { Randomized case } \\
\text { control prospective } \\
\text { study }\end{array}$ & 44 & $\begin{array}{l}\text { Balloon occlusion method in endoscopic submucosal } \\
\text { dissection reduces harmful influences }\end{array}$ & No \\
\hline Nonaka et al. ${ }^{14}$ & 2010 & $\begin{array}{l}\text { Randomized } \\
\text { prospective study }\end{array}$ & 89 & $\begin{array}{l}\text { Carbon dioxide is as safe as air insufflation in upper } \\
\text { endoscopic submucosal dissection for patients un- } \\
\text { der deep sedation }\end{array}$ & No \\
\hline
\end{tabular}

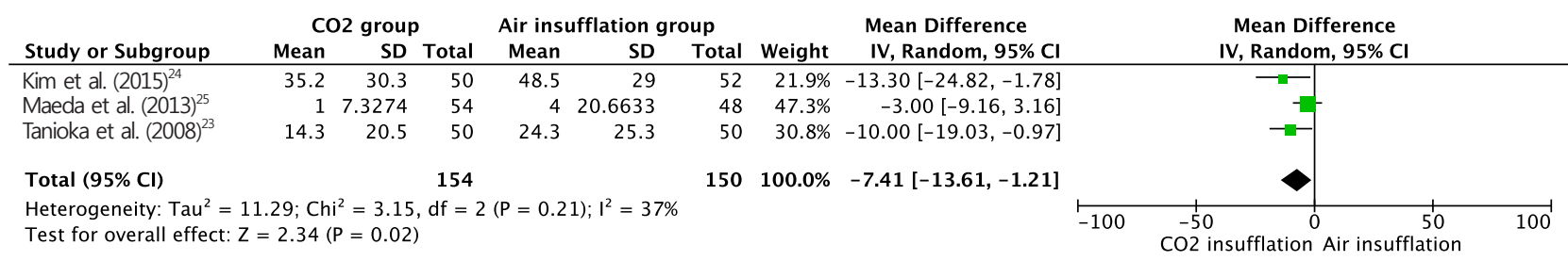

Fig. 2. Forest plot of maximal post-operative pain. $\mathrm{CO}_{2}$, carbon dioxide; $\mathrm{SD}$, standard deviation; $\mathrm{Cl}$, confidence interval.

3). No death was reported in any of the studies. The total number of post-procedural hemorrhages and perforations was 30 and 11, respectively. The difference in post-procedural hemorrhage between the two groups was not significant (OR, 0.51 ; $95 \%$ CI, 0.22-1.19; $p=0.12$; Fig. 5). Similarly, no significant difference in the rate of perforation was found (OR, 0.39 ; 95\% CI, 0.10-1.57; $p=0.19$; Fig. 6). Statistical significance was also calculated for overall adverse events. The incidence of overall adverse events was significantly lower in the $\mathrm{CO}_{2}$ group (OR, 0.51; CI 0.32-0.84; $p=0.007$; Fig. 7). The study by Takada et al. uniquely reported Mallory-Weiss tear as a separate category, and its occurrence was significantly lower in the $\mathrm{CO}_{2}$ group compared to the air insufflation group $(p=0.013)^{26}$ 


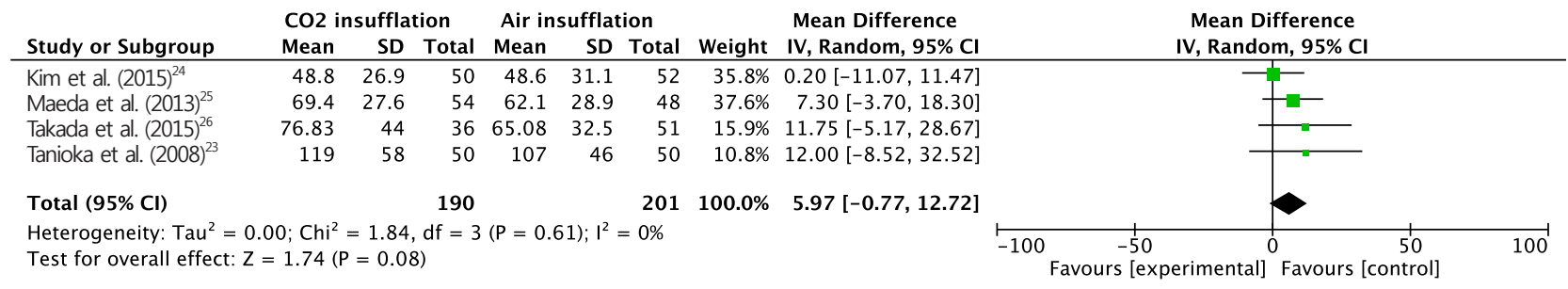

Fig. 3. Forest plot of procedure time. $\mathrm{CO}_{2}$, carbon dioxide; $\mathrm{SD}$, standard deviation; $\mathrm{Cl}$, confidence interval.

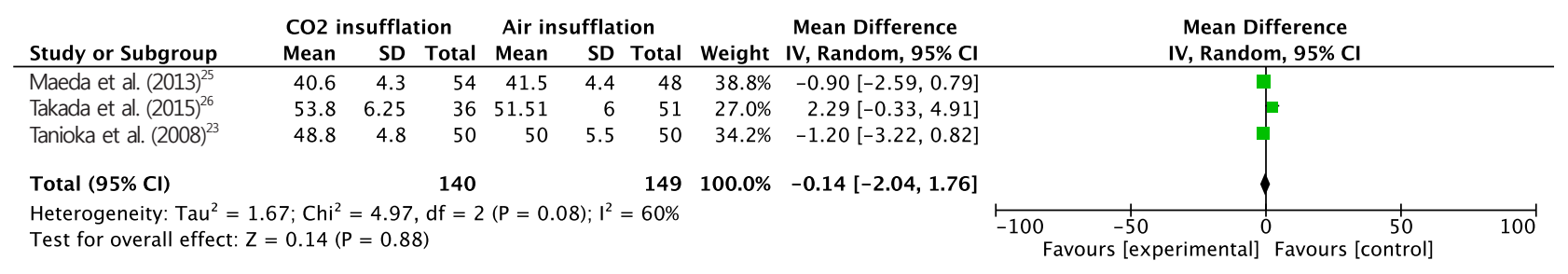

Fig. 4. Forest plot of end-tidal carbon dioxide $\left(\mathrm{CO}_{2}\right)$. SD, standard deviation; $\mathrm{Cl}$, confidence interval.

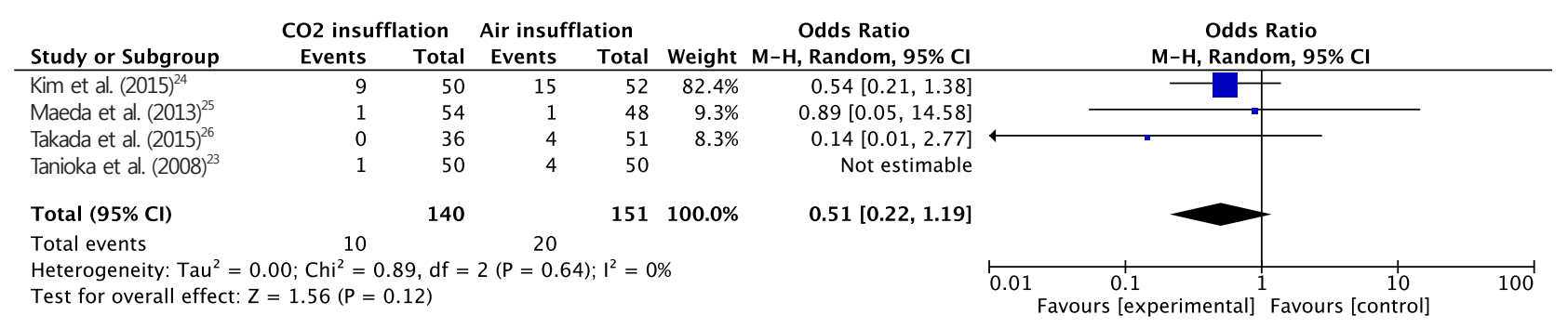

Fig. 5. Forest plot of post-operative hemorrhage. $\mathrm{CO}_{2}$, carbon dioxide; $\mathrm{Cl}$, confidence interval.

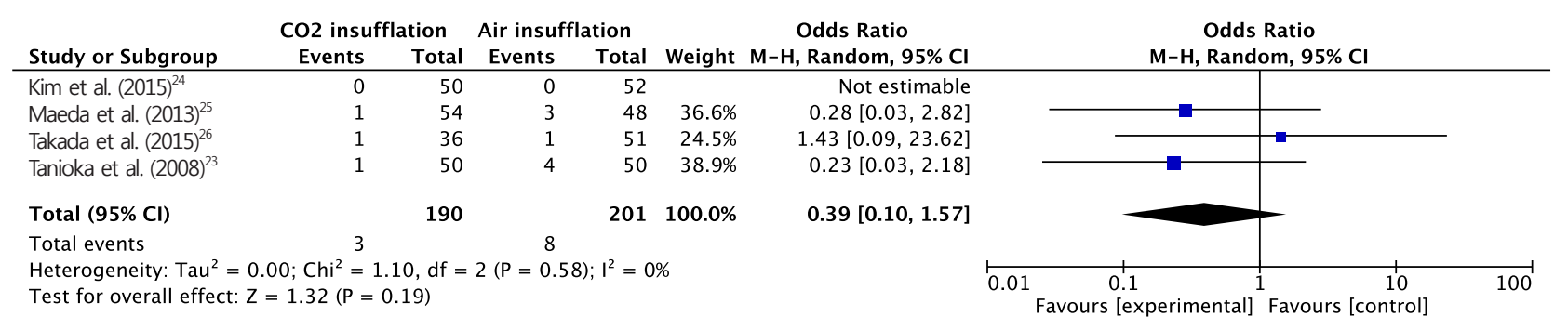

Fig. 6. Forest plot of perforation rate. $\mathrm{CO}_{2}$, carbon dioxide; $\mathrm{Cl}$, confidence interval.

\section{DISCUSSION}

As in any endoscopic procedure, adequate gastric distention is required for the safe advancement of the scope and adequate visualization of the mucosa during ESD. Although it is universally available, ambient air is poorly absorbed by the GI tract, causing excessive post-operative distention of the bowel lumen and consequent pain and discomfort. ${ }^{31}$ On the contrary, $\mathrm{CO}_{2}$ is absorbed approximately 160 times faster than nitrogen (a major gaseous ingredient of ambient air) into gut mucosa and is rapidly exhaled through the lungs, resulting in reduced gut distention. This leads to significantly less post-procedural pain and discomfort, and improved recovery times, which has been proven in multiple previous studies on GI endoscopy. ${ }^{13,15,31-34}$ To the best of our knowledge, this is the first review comparing $\mathrm{CO}_{2}$ to air insufflation in gastric ESD. Our analysis of 391 patients showed significantly less post-operative pain in the $\mathrm{CO}_{2}$ insufflation group, which is attributable to the shorter duration of bowel distention. Pain associated with the procedure was analyzed in three of the four trials. ${ }^{23-25}$ Kim et al. and Tanioka et al. showed that there were significantly lower mean pain scores in the $\mathrm{CO}_{2}$ group compared with the air insufflation group $\left(p=0.028\right.$ and $p=0.04$, respectively) ${ }^{23,24}$ As a result, patients in 


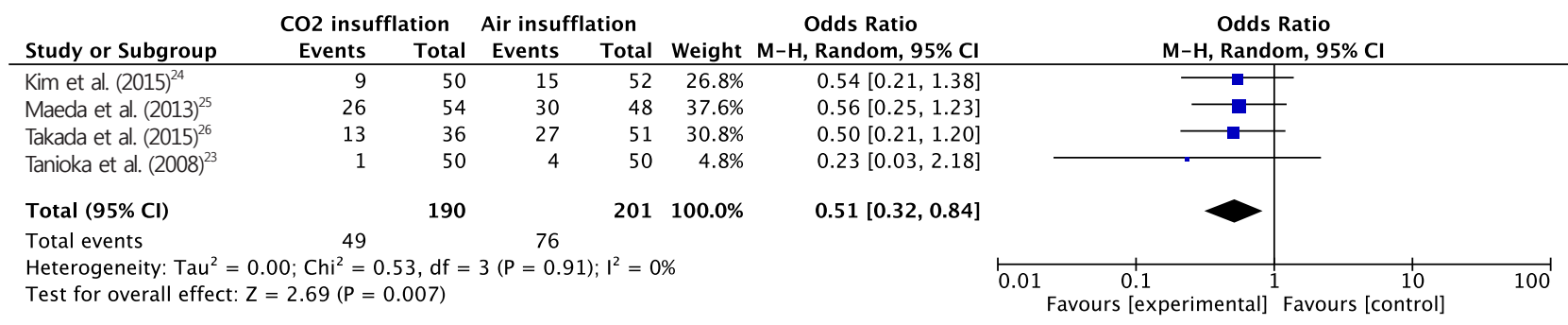

Fig. 7. Forest plot of overall adverse event. $\mathrm{CO}_{2}$, carbon dioxide; $\mathrm{Cl}$, confidence interval.

the air insufflation group requested more analgesics for pain control. This finding has been corroborated by other studies and meta-analyses done on sigmoidoscopy, colonoscopy, double-balloon enteroscopy, and endoscopic retrograde cholangiopancreatography. ${ }^{12,13,15,31,33-39}$ However, the study by Maeda et al. ${ }^{25}$ showed no significant difference in pain levels between the two groups. We believe this is due to the strong analgesic effect of pentazocine, which was used in both groups in that study. Otherwise, significant discomfort can be expected in the air insufflation group, in which a mean of $1,037 \mathrm{~mL}$ of residual gas in the GI tract was observed post-operatively compared with that of $643 \mathrm{~mL}$ in the $\mathrm{CO}_{2}$ group $(p<0.001)$.

The other important consideration in this study was the procedure time, which was not significantly different between the two groups. The implications of this finding are three-fold. First, it shows that the type of gas used does not influence the length of the procedure. Second, the endoscopists in both groups were equally skilled. This finding is substantiated by the fact that all the procedures were performed by endoscopists with years of experience in therapeutic GI endoscopy at high-volume tertiary care centers. Third, the comparison of end-tidal $\mathrm{CO}_{2}$ between the two groups increases in reliability as a result. The end-tidal $\mathrm{CO}_{2}$ increased significantly from baseline in both groups in the study by Takada et al. ${ }^{26}$ however, our study failed to show a difference in maximal end-tidal $\mathrm{CO}_{2}$ between the two groups. This result is in accordance with previous data on the safety of $\mathrm{CO}_{2}$ in various GI endoscopic procedures. ${ }^{14,40,41}$ However, most of those studies did not include patients with significant pulmonary dysfunction. On the other hand, some other studies conducted on patients with pulmonary dysfunction also failed to show significant $\mathrm{CO}_{2}$ retention, acidosis, or narcosis, and $\mathrm{CO}_{2}$ was found to be safe in terms of adverse event risks and hospital stay. In those studies, the only significant correlation that was found was between the length of the procedure and an elevation in end-tidal $\mathrm{CO}_{2}{ }^{22}$ In fact, $\mathrm{CO}_{2}$ insufflation has been found to be safe even in patients with obstructive ventilatory disturbances in various gastric and non-gastric ESD studies. ${ }^{11,42}$ Moreover, end-tidal $\mathrm{CO}_{2}$ remained within acceptable limits even in the context of pro- longed procedure time in those studies. ${ }^{21,40}$ In general, there is a paucity of data demonstrating $\mathrm{CO}_{2}$ retention in patients with pulmonary dysfunction in ESD.

In terms of adverse events, the rate of procedure-related hemorrhage and bowel perforation did not reach a statistically significant level between the two groups since only four trials were included in the study. Additionally, all studies were conducted in high-volume medical centers by experts in their field, which naturally led to a lower rate of adverse events. However, the overall adverse event rate was significantly lower in the $\mathrm{CO}_{2}$ insufflation group. In the study by Takada et al., ${ }^{26} \mathrm{CO}_{2}$ insufflation was shown to confer the benefit of reducing the risk of Mallory-Weiss tears $(p=0.013)$. Again, this is due to the more rapid absorption of $\mathrm{CO}_{2}$ compared with air, which resulted in a significantly lower overall adverse event rate in the $\mathrm{CO}_{2}$ group in our study. Although no life-threatening adverse events were reported in our study, air insufflation is known to cause adverse events such as perforation, tension pneumothorax, air embolism, mediastinal emphysema, and abdominal compartment syndrome during endoscopic procedures. ${ }^{43-46} \mathrm{CO}_{2}$ insufflation would be advantageous in such situations, as it is more rapidly absorbed into the blood and cleared by the lungs. Our study had a few limitations. The main limiting factor of our study is the low number of included studies due to the small number of published RCTs. Additionally, the studies did not include patients with significant pulmonary dysfunction.

In conclusion, $\mathrm{CO}_{2}$ insufflation appears to be safe and effective for gastric ESD. It significantly decreases post-procedural pain and discomfort and neither prolongs the procedure time, nor significantly increases end-tidal $\mathrm{CO}_{2}$. Lastly, fewer overall adverse events were observed in the $\mathrm{CO}_{2}$ insufflation group during ESD.

Conflicts of Interest

The authors have no financial conflicts of interest.

\section{Acknowledgments}

The authors thank William Scales and Komal Chughtai for proofreading the manuscript. 


\section{REFERENCES}

1. National Cancer Institute. Cancer stat facts: stomach cancer [Internet]. Rockville (MD): National Cancer Institute; c2016 [cited 2016 Nov 1]. Available from: http://seer.cancer.gov/statfacts/html/stomach.html.

2. World Health Organization. Cancer [Internet]. Geneva: World Health Organization; c2017 [updated 2017 Feb; cited 2016 Nov 1]. Available from: http://www.who.int/mediacentre/factsheets/fs297/en/.

3. Noguchi Y, Yoshikawa T, Tsuburaya A, Motohashi H, Karpeh MS, Brennan MF. Is gastric carcinoma different between Japan and the United States? Cancer 2000;89:2237-2246.

4. Gotoda T, Jung HY. Endoscopic resection (endoscopic mucosal resection/ endoscopic submucosal dissection) for early gastric cancer. Dig Endosc 2013;25 Suppl 1:55-63.

5. Gotoda T, Yamamoto H, Soetikno RM. Endoscopic submucosal dissection of early gastric cancer. J Gastroenterol 2006;41:929-942.

6. Oda I, Saito D, Tada M, et al. A multicenter retrospective study of endoscopic resection for early gastric cancer. Gastric Cancer 2006;9:262-270.

7. Oka S, Tanaka S, Kaneko I, et al. Advantage of endoscopic submucosal dissection compared with EMR for early gastric cancer. Gastrointest Endosc 2006;64:877-883.

8. Watanabe K, Ogata S, Kawazoe S, et al. Clinical outcomes of EMR for gastric tumors: historical pilot evaluation between endoscopic submucosal dissection and conventional mucosal resection. Gastrointest Endosc 2006;63:776-782.

9. Onozato $\mathrm{Y}$, Ishihara H, Iizuka H, et al. Endoscopic submucosal dissection for early gastric cancers and large flat adenomas. Endoscopy 2006;38:980-986

10. Fujishiro M. Endoscopic submucosal dissection for stomach neoplasms. World J Gastroenterol 2006;12:5108-5112.

11. Takano A, Kobayashi M, Takeuchi M, et al. Capnographic monitoring during endoscopic submucosal dissection with patients under deep sedation: a prospective, crossover trial of air and carbon dioxide insufflations. Digestion 2011;84:193-198.

12. Sumanac K, Zealley I, Fox BM, et al. Minimizing postcolonoscopy abdominal pain by using $\mathrm{CO}_{2}$ insufflation: a prospective, randomized, double blind, controlled trial evaluating a new commercially available $\mathrm{CO}_{2}$ delivery system. Gastrointest Endosc 2002;56:190-194.

13. Church J, Delaney C. Randomized, controlled trial of carbon dioxide insufflation during colonoscopy. Dis Colon Rectum 2003;46:322-326.

14. Nonaka S, Saito Y, Takisawa H, Kim Y, Kikuchi T, Oda I. Safety of carbon dioxide insufflation for upper gastrointestinal tract endoscopic treatment of patients under deep sedation. Surg Endosc 2010;24:16381645.

15. Bretthauer M, Thiis-Evensen E, Huppertz-Hauss G, et al. NORCCAP (Norwegian colorectal cancer prevention): a randomised trial to assess the safety and efficacy of carbon dioxide versus air insufflation in colonoscopy. Gut 2002;50:604-607.

16. Maeda Y, Hirasawa D, Fujita N, et al. A pilot study to assess mediastinal emphysema after esophageal endoscopic submucosal dissection with carbon dioxide insufflation. Endoscopy 2012;44:565-571.

17. Saltzman HA, Sieker HO. Intestinal response to changing gaseous environments: normobaric and hyperbaric observations. Ann N Y Acad Sci 1968;150:31-39.

18. Beller EM, Glasziou PP, Altman DG, et al. PRISMA for abstracts: reporting systematic reviews in journal and conference abstracts. PLoS Med 2013;10:e1001419.

19. Wright RW, Brand RA, Dunn W, Spindler KP. How to write a systematic review. Clin Orthop Relat Res 2007;455:23-29.

20. Mori H, Kobara H, Muramatsu A, et al. Comparison of postoperative complications after endoscopic submucosal dissection: differences of insufflations and anesthesias. Diagn Ther Endosc 2011;2011:709237.

21. Suzuki T, Minami H, Komatsu T, et al. Prolonged carbon dioxide insufflation under general anesthesia for endoscopic submucosal dissection.
Endoscopy 2010;42:1021-1029.

22. Takada J, Araki H, Onogi F, et al. Safety of carbon dioxide insufflation during gastric endoscopic submucosal dissection in patients with pulmonary dysfunction under conscious sedation. Surg Endosc 2015;29:1963-1969.

23. Tanioka D, Kawahara Y, Okada H, et al. Safety and efficacy of carbon dioxide $\left(\mathrm{CO}_{2}\right)$ insufflation during endoscopic submucosal dissection (ESD) for gastric cancer under propofol sedation: a randomized, controlled trial. Gastrointest Endosc 2008;67:AB279.

24. Kim SY, Chung JW, Park DK, Kwon KA, Kim KO, Kim YJ. Efficacy of carbon dioxide insufflation during gastric endoscopic submucosal dissection: a randomized, double-blind, controlled, prospective study. Gastrointest Endosc 2015;82:1018-1024.

25. Maeda Y, Hirasawa D, Fujita N, et al. A prospective, randomized, double-blind, controlled trial on the efficacy of carbon dioxide insufflation in gastric endoscopic submucosal dissection. Endoscopy 2013;45:335341.

26. Takada J, Araki H, Onogi F, et al. Safety and efficacy of carbon dioxide insufflation during gastric endoscopic submucosal dissection. World J Gastroenterol 2015;21:8195-8202.

27. Verhagen AP, de Vet HC, de Bie RA, et al. The Delphi list: a criteria list for quality assessment of randomized clinical trials for conducting systematic reviews developed by Delphi consensus. J Clin Epidemiol 1998;51:1235-1241.

28. Kontopantelis E, Springate DA, Reeves D. A re-analysis of the cochrane library data: the dangers of unobserved heterogeneity in meta-analyses. PLoS One 2013;8:e69930.

29. Hozo SP, Djulbegovic B, Hozo I. Estimating the mean and variance from the median, range, and the size of a sample. BMC Med Res Methodol 2005;5:13.

30. Hawker GA, Mian S, Kendzerska T, French M. Measures of adult pain: visual analog scale for pain (VAS Pain), numeric rating scale for pain (NRS Pain), McGill pain questionnaire (MPQ), short-form McGill pain questionnaire (SF-MPQ), chronic pain grade scale (CPGS), short form36 bodily pain scale (SF-36 BPS), and measure of intermittent and constant osteoarthritis pain (ICOAP). Arthritis Care Res (Hoboken) 2011;63 Suppl 11:S240-S252.

31. Wang WL, Wu ZH, Sun Q, et al. Meta-analysis: the use of carbon dioxide insufflation vs. room air insufflation for gastrointestinal endoscopy. Aliment Pharmacol Ther 2012;35:1145-1154.

32. ASGE Technology Committee, Lo SK, Fujii-Lau LL, et al. The use of carbon dioxide in gastrointestinal endoscopy. Gastrointest Endosc 2016;83:857-865.

33. Dellon ES, Hawk JS, Grimm IS, Shaheen NJ. The use of carbon dioxide for insufflation during GI endoscopy: a systematic review. Gastrointest Endosc 2009;69:843-849.

34. Maple JT, Keswani RN, Hovis RM, et al. Carbon dioxide insufflation during ERCP for reduction of postprocedure pain: a randomized, double-blind, controlled trial. Gastrointest Endosc 2009;70:278-283.

35. Bretthauer M, Seip B, Aasen S, Kordal M, Hoff G, Aabakken L. Carbon dioxide insufflation for more comfortable endoscopic retrograde cholangiopancreatography: a randomized, controlled, double-blind trial. Endoscopy 2007;39:58-64.

36. Bretthauer M, Hoff G, Thiis-Evensen E, et al. Carbon dioxide insufflation reduces discomfort due to flexible sigmoidoscopy in colorectal cancer screening. Scand J Gastroenterol 2002;37:1103-1107.

37. Stevenson GW, Wilson JA, Wilkinson J, Norman G, Goodacre RL. Pain following colonoscopy: elimination with carbon dioxide. Gastrointest Endosc 1992;38:564-567.

38. Wong JC, Yau KK, Cheung HY, Wong DC, Chung CC, Li MK. Towards painless colonoscopy: a randomized controlled trial on carbon dioxide-insufflating colonoscopy. ANZ J Surg 2008;78:871-874.

39. Shi H, Chen S, Swar G, Wang Y, Ying M. Carbon dioxide insufflation during endoscopic retrograde cholangiopancreatography: a review and meta-analysis. Pancreas 2013;42:1093-1100. 
40. Kikuchi T, Fu KI, Saito Y, et al. Transcutaneous monitoring of partial pressure of carbon dioxide during endoscopic submucosal dissection of early colorectal neoplasia with carbon dioxide insufflation: a prospective study. Surg Endosc 2010;24:2231-2235.

41. Saito Y, Uraoka T, Matsuda T, et al. A pilot study to assess the safety and efficacy of carbon dioxide insufflation during colorectal endoscopic submucosal dissection with the patient under conscious sedation. Gastrointest Endosc 2007;65:537-542.

42. Yoshida M, Imai K, Hotta K, et al. Carbon dioxide insufflation during colorectal endoscopic submucosal dissection for patients with obstructive ventilatory disturbance. Int J Colorectal Dis 2014;29:365-371.

43. Maeda Y, Hirasawa D, Fujita N, et al. Carbon dioxide insufflation in esophageal endoscopic submucosal dissection reduces mediastinal emphysema: a randomized, double-blind, controlled trial. World J Gastroenterol 2016;22:7373-7382.

44. Rai A, Iftikhar S. Tension pneumothorax complicating diagnostic upper endoscopy: a case report. Am J Gastroenterol 1999;94:845-847.

45. Green BT, Tendler DA. Cerebral air embolism during upper endoscopy: case report and review. Gastrointest Endosc 2005;61:620-623.

46. Hayakawa M, Gando S, Kameue T, Morimoto Y, Kemmotsu O. Abdominal compartment syndrome and intrahepatic portal venous gas: a possible complication of endoscopy. Intensive Care Med 2002;28:16801681. 